\section{PEDIOMATERNAL NURSING JOURNAL}

Vol. 7, No. 1, March 2021

Journal Homepage: https://e-journal.unair.ac.id/PMNJ/ http://dx.doi.org/10.20473/pmnj.v7i1.24184

Review

\title{
Low-Hemoglobin Levels During Pregnancy with Low-Birth Weight: A Systematic Review and Meta-Analysis
}

\author{
Lucyana Septia Pramita1 $^{(D)}$, Widati Fatmaningrum² ${ }^{\circledR}$, Martono Tri Utomo ${ }^{3}$ (D), \\ Muhammad Ilham Aldika Akbar ${ }^{4}$ (D) \\ 1 Midwifery Bachelor's Degree, Universitas Airlangga, Surabaya, Indonesia \\ 2 Department of Public Health Science, Faculty of Medicine, Universitas Airlangga, Surabaya, Indonesia \\ ${ }^{3}$ Department of Pediatric, Faculty of Medicine, Universitas Airlangga, Surabaya, Indonesia \\ ${ }^{4}$ Department of Obstetrics and Gynaecology, Faculty of Medicine, Universitas Airlangga, Surabaya, Indonesia
}

\section{ARTICLE HISTORY}

Received: Dec 20, 2021

Accepted: July 18, 2021

Published: July 18, 2021

\section{KEYWORDS}

maternal hemoglobin; anemia; low birth weight

\section{CORRESPONDING AUTHOR}

Lucyana Septia Pramita lucyanaseptiap@gmail.com Midwifery Bachelor's Degree, Universitas Airlangga, Surabaya, Indonesia

Cite this as:

\begin{abstract}
Introduction: Low birth weight (LBW) is one of the main risk factors for neonatal morbidity and mortality. Anemia in developing countries is still quite high compared to developed countries. Low hemoglobin levels in pregnancy can affect the birth of low birth weight babies.

Methods: This study used a systematic review method. Studies published between 2015 and 2019. Search for articles was reviewed systematically through Scopus, ScienceDirect, Cochrane, and PubMed databases. The final results obtained 10 articles following the inclusion and exclusion criteria. Calculation result using Meta-Analysis with help of Comprehensive MetaAnalysis (CMA) software.

Results: Compare the odds ratio and confidence interval of hemoglobin levels compared to low birth weight events. The results obtained OR 1.449 (95\% CI $0.964-2.177$ ) and p-Value 0.074 so that there is no relationship of hemoglobin levels in pregnant women $\leq 11 \mathrm{gr} / \mathrm{dL}$ with the incidence of low birth weight babies. In the heterogeneity test results, I-Squared results obtained by $79.191 \%$, which indicates the value of I-squared heterogeneity> $50 \%$ so that the sample used is heterogeneous. Maternal age less than 20 years or more than 35 years, number of parity, pregnancy spacing, and number of problems in the assessment of pregnancy and previous labor.
\end{abstract}

Conclusion: There is no correlation between low maternal hemoglobin levels with the incidence of low birth weight because there are other factors that can affect outcomes such as different respondent characteristics, number of samples, different research countries, different trimester of pregnancy and other factors that can cause research bias.

Pramita, L, S., Fatmaningrum, W., Utomo, M, T., Akbar, M, I, A. (2021). Low-Hemoglobin Levels During Pregnancy with Low-Birth Weight: A Systematic Review and Meta-Analysis. Pediomaternal Nurs. J., 7(1), 55-64. Doi: http://dx.doi.org/10.20473/pmnj.v7i1.24184 


\section{INTRODUCTION}

Low birth weight are one of the main risk factors for neonatal death. Low birth weight babies (LBW) according to the World Health Organization (WHO) can be defined as babies with birth weight $<2,500$ grams. Some of the factors causing low birth weight babies are maternal factors (maternal age, gestational distance, parity, hemoglobin levels, obstetric and nutritional history), placental factors, environmental factors, mother's educational status and socio-economic status. Low hemoglobin levels in pregnant women can cause anemia. Anemia in pregnancy will interfere with oxygenation and the supply of nutrients from the mother to the fetus. As a result, the fetus will experience weight gain problems, causing LBW. One of the causes of anemia in pregnant women is a lack of iron intake during pregnancy (Novianti and Aisyah, 2018).

In developing countries anemia that is often found in pregnant women is iron deficiency anemia. Iron deficiency anemia is considered as one of the contributors to the global disease burden. The prevalence of pregnant women with iron deficiency anemia was $25.7 \%$ and $52 \%$ of them had depleted iron stores (Srour et al., 2018). Iron deficiency anemia is anemia caused by a lack of iron in the blood. Lack of iron levels in the blood can affect hemoglobin concentration (Fitriany and Saputri, 2018). According to The United Nations Children's Fund (UNICEF) and World Health Organization

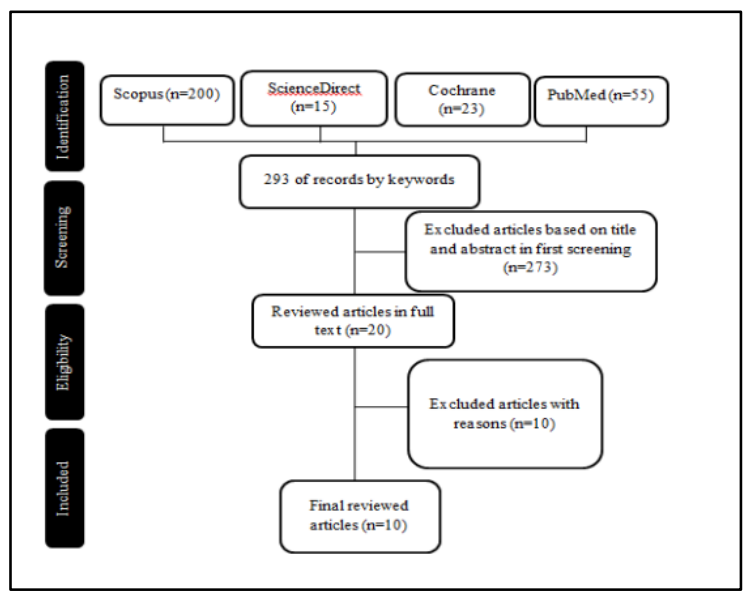

Figure 1. PRISMA Flowchart of screening process
(WHO) in 2004, the incidence of LBW is estimated to be more than 20 million babies worldwide, amounting to $15.5 \%$ of all births, who are born with low birth weight of $95.6 \%$ of them in developing countries. Low birth weight rates in developing countries as much as $16.5 \%$. More than double of the developed area at $7 \%$. Based on data from the World Health Rankings in 2014, Indonesia ranks $70^{\text {th }}$ with the highest percentage of deaths due to low birth weight babies, which is $10.6 \%$. This study aims to provide summary results of previous studies about this topic.

\section{METHOD}

\subsection{Design}

This research was a secondary study using a systematic review and meta-analysis.

\subsection{Searching Strategy}

For search strategy, we searched the Scopus, ScienceDirect, Cochrane, and Pubmed databases to identify relevant studies. We used the following search terms: ("Maternal Hemoglobin") AND ("Anemia") AND ("Low Birth Weight" OR LBW) this systematic review only re-identified pooled data from primer studies. The inclusion criteria of this study are: (1) literature in English; (2) research published in the last 5 years (20152019 period); (3) open access; (4) full text accessible literature. Exclusion criteria are: (1) Non-primary studies such as review article, case report, conference result or book chapters; (2) intervention studies; (3) pregnant women with preeclampsia, eclampsia, hypertension, heart defects and diabetes mellitus; (4) babies with amusement, hydroamnion and congenital abnormalities.

The literature search process is reported in the PRISMA flowchart. The PRISMA flowchart is a protocol with completed and detailed steps. For quality assessment and data extraction, we measured the quality of study using a quality assessment tool for quantitative studies from EPHPP (Effective Public Health Practice Project). There are 6 components assessed in this assessment tool such as selection bias, study design, confounders, blinding, data collection method, withdrawals, and dropouts. Each component is graded with 3 ratings (1= 
Table 1. Quality Ratings of Studies.

\begin{tabular}{lccccccc}
\hline Authors & $\begin{array}{c}\text { Selection } \\
\text { bias }\end{array}$ & $\begin{array}{c}\text { Study } \\
\text { design }\end{array}$ & Confounders & Blinding & $\begin{array}{c}\text { Data } \\
\text { collection } \\
\text { method }\end{array}$ & $\begin{array}{c}\text { Withdrawals } \\
\text { and } \\
\text { dropouts }\end{array}$ & Rating \\
\hline Aboye (2018) & 1 & 2 & 3 & 2 & 1 & 2 & 2 \\
Ahankari (2017) & 1 & 2 & 1 & 2 & 2 & 2 & 1 \\
Girma (2019) & 1 & 2 & 3 & 2 & 2 & 2 & 2 \\
Hailu, (2018) & 2 & 2 & 3 & 2 & 2 & 2 & 2 \\
Heydarpour (2019) & 1 & 2 & 1 & 2 & 2 & 2 & 1 \\
Kumari (2019) & 1 & 2 & 1 & 2 & 1 & 2 & 1 \\
Nazirun (2019) & 1 & 2 & 3 & 2 & 2 & 2 & 2 \\
Oladeinde, (2015) & 2 & 2 & 3 & 2 & 1 & 2 & 1 \\
Roopnarine (2017) & 1 & 2 & 1 & 2 & 1 & 1 & 2 \\
Sharma, (2015) & 2 & 2 & 1 & 2 & & & 2 \\
\hline Description
\end{tabular}

Description on the rating:

1 = Strong (There is no weak value)

2 = Moderate (There is one weak value)

3 = Weak (There are two or more weak values)

strong, $2=$ moderate, $3=$ weak). After evaluating each component, it can be concluded that the global rating for the paper is STRONG if there was no weak rating, MODERATE if there was one weak rating, and WEAK if there were two or more weak ratings. For each study, we extract the following information: author, title, method of studies, independent variable, dependent variable, result.

\subsection{Analysis}

Odds ratio (OR) and 95\% confidence interval (CI) were calculated based on the event numbers exreacted from each study before data pooling. Statistical analysis was performed using the Comprehensive. The heterogeneity among the studies was quantified and tested using the $\mathrm{I}^{2}$ statistic, which represents the percentage of total variation across studies due to heterogeneity rather than chance. The assumption of heterogeneity was considered if $\mathrm{I}^{2}$ values $50 \%$ or less, whereas if $\mathrm{I}^{2}$ values $>50 \%$ indicate that the studies were heterogeneous. Statistical analysis was performed using the Comprehensive Meta-Analysis (CMA) software. This analysis was carried out using 2 methods, the fixed-effect model for homogeneous articles and the random-effect model for heterogeneous articles. The Summary OR and CI from the analysis result carried out according to the model (fixed/random effect model), were also displayed to describe the overall treatment effect

\section{RESULT}

\subsection{Overview of the Studies}

The literature search was carried out through the Scopus, ScienceDirect, Cochrane, and PubMed databases. The total articles obtained through 4 electronic databases were 293 research articles obtained based on keywords, the next stage was the screening process based on the title and abstract that were in accordance with the research topic, so that 273 research articles were excluded because they were less relevant, there were the remaining 20 research articles reviewed in full text of the literature. In the next stage, 10 articles were excluded so that in the final stage, 10 articles were obtained that match the inclusion and exclusion criteria to be included in a systematic review. The following is a prism flowchart image (Figure 1):

\subsection{Characteristic of Studies Included}

The author, methodology, variable and outcomes were identified and summarized in Table 1 . The 10 studies consist of three articles were cross-sectional study $(1,6,8)$, two articles were retrospective study $(2,5)$, four articles were case control study $(3,4,7,9)$ and one was a retrospective case control study (10). From 10 articles that were reviewed, five were studies in Asia $(2,5,6,7,10)$ and five were studies in Africa country $(1,3,4,8,9)$. All studies were included in the quality assessment with EPHPP tools 


\section{Hemoglobin Level $\leq 11 \mathrm{gr} / \mathrm{dL}$}

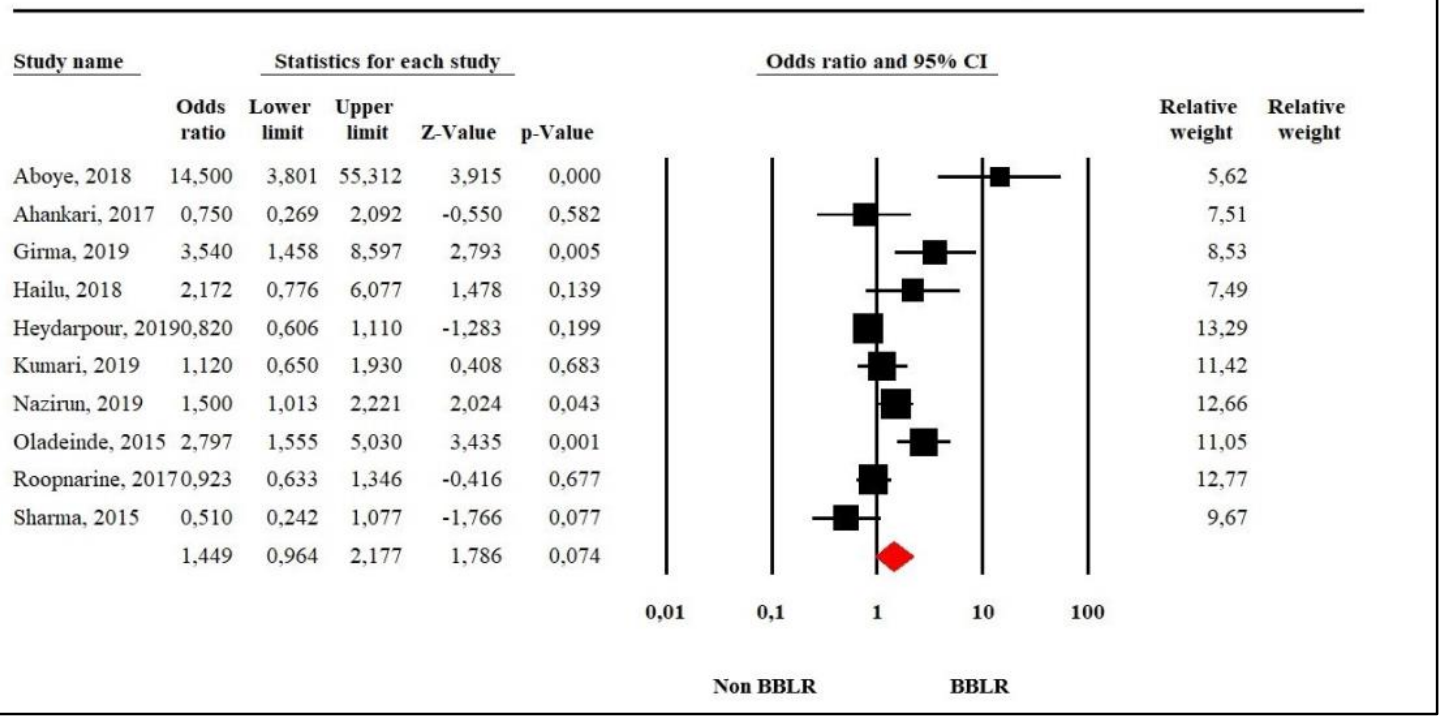

Figure 2. Forest Plot Meta-Analysis Results

\begin{tabular}{|c|c|c|c|c|c|c|c|c|c|c|c|c|c|c|}
\hline \multicolumn{2}{|l|}{ Model } & \multicolumn{3}{|c|}{ Effect size and $95 \%$ interval } & \multicolumn{3}{|c|}{ Test of null (2--Tail) } & \multicolumn{4}{|c|}{ Heterogeneity } & \multicolumn{3}{|c|}{ Tau-squared } \\
\hline Model & $\begin{array}{l}\text { Number } \\
\text { Studies }\end{array}$ & $\begin{array}{l}\text { Point } \\
\text { Pestimate }\end{array}$ & $\begin{array}{l}\text { Lower } \\
\text { limit }\end{array}$ & $\begin{array}{c}\text { Upper } \\
\text { limit }\end{array}$ & Z-value & P-value & Q-value & $\mathrm{df}(Q)$ & P-value & 1-squared & $\begin{array}{c}\text { Sau } \\
\text { Squared }\end{array}$ & $\begin{array}{c}\text { Standard } \\
\text { Error }\end{array}$ & Variance & Tаu \\
\hline Fixed & 10 & 1,168 & 0,999 & 1,379 & 1.833 & 0.067 & 432.251 & 9 & 0,000 & 79,191 & 0.301 & 0,217 & 0,047 & 0,548 \\
\hline Random & 10 & 1.449 & 0.964 & 2,177 & 1,786 & 0,074 & & & & & & & & \\
\hline
\end{tabular}

Figure 3. Heterogeneity Test Results

(Table 2). Five studies were categorized as a strong and five studies were moderate rating (Table 1).

\subsection{Outcome}

There are 10 literatures that report the incidence of low birth weight with anemia, specifically Hemoglobin levels $\leq 11 \mathrm{gr} / \mathrm{dL}$ with the results of the random effect model obtained OR 1.449 (95\% CI 0.964 - 2.177) and $p$-value 0.074 . This shows that $p$-value is $\geq 0.05$, which means that in this studies there is no significant correlation between low hemoglobin levels in pregnant women and the incidence of low birth weight (Figure 2). In the heterogeneity test results it can be seen in the I-Squared results of $79.191 \%$, which indicates that the I-squared heterogeneity value $>50 \%$ (Figure 3 )

\section{DISCUSSION}

The results of the meta-analysis showed a pvalue of 0.074 . This shows that there is no significant relationship between low maternal hemoglobin levels and the incidence of low birth weight babies. There were other factors that influenced the results such as different characteristics, studies in different countries, sample size and other factors that could cause bias. Anemia in developing countries, especially in Indonesia, which is most commonly found in pregnant women is iron deficiency anemia. Iron deficiency anemia is anemia that occurs due to a lack of iron in the blood, which means that the concentration of hemoglobin in the blood is reduced due to disruption in the formation of red blood cells due to lack of iron levels in the blood (Fitriany and Saputri, 2018). 
Table 2. Summary of the Literatures.

\begin{tabular}{|c|c|c|c|c|c|}
\hline Authors & Article Title & $\begin{array}{l}\text { Research } \\
\text { Methods }\end{array}$ & $\begin{array}{c}\text { Independent } \\
\text { Variable }\end{array}$ & $\begin{array}{c}\text { Dependent } \\
\text { Variable }\end{array}$ & Result \\
\hline $\begin{array}{l}\text { Aboye et } \\
\text { al., } 2018\end{array}$ & $\begin{array}{l}\text { Prevalence and } \\
\text { associated } \\
\text { factors of } \\
\text { lowbirth weight } \\
\text { in Axum town, } \\
\text { Tigray, North } \\
\text { Ethiopia. }\end{array}$ & $\begin{array}{l}\text { Cross- } \\
\text { sectional } \\
\text { study }\end{array}$ & $\begin{array}{l}\text { Demographic } \\
\text { and socio- } \\
\text { economics, } \\
\text { Maternal } \\
\text { anthropometry, } \\
\text { Obstetric and } \\
\text { gynecologic } \\
\text { factors }\end{array}$ & $\begin{array}{l}\text { Low birth } \\
\text { weight }\end{array}$ & $\begin{array}{l}\text { Maternal height, gestational age, } \\
\text { ANC, anemia during pregnancy } \\
\text { and drinking alcohol were found } \\
\text { to be significantly with low birth } \\
\text { weight }(p=0.000)\end{array}$ \\
\hline $\begin{array}{l}\text { Ahankari } \\
\text { et al., } \\
2017\end{array}$ & $\begin{array}{l}\text { Factors } \\
\text { associated with } \\
\text { preterm delivery } \\
\text { and low birth } \\
\text { weight: A study } \\
\text { from rural } \\
\text { Maharashtra, } \\
\text { India. }\end{array}$ & $\begin{array}{l}\text { Retrospec } \\
\text { tive study }\end{array}$ & $\begin{array}{l}\text { Maternal age, } \\
\text { Gravidity, } \\
\text { Maternal anemia } \\
\text { status }\end{array}$ & $\begin{array}{l}\text { Low birth } \\
\text { weight }\end{array}$ & $\begin{array}{l}\text { In mothers aged }<22 \text { years who } \\
\text { are likely to deliver LBW babies, } \\
\text { Primigravidas are twice as likely } \\
\text { to deliver LBW babies compared } \\
\text { to multigravidas. Maternal } \\
\text { anemia was not significant with } \\
\text { the incident of LBW babies ( } \mathrm{p}= \\
0.58 \text { ) }\end{array}$ \\
\hline $\begin{array}{l}\text { Girma et } \\
\text { al., } 2019\end{array}$ & $\begin{array}{l}\text { Factors } \\
\text { associated with } \\
\text { low birth weight } \\
\text { among newborns } \\
\text { delivered at } \\
\text { public health } \\
\text { facilities of } \\
\text { Nekemte town, } \\
\text { West Ethiopia: A } \\
\text { case control } \\
\text { study. }\end{array}$ & $\begin{array}{l}\text { Case } \\
\text { control } \\
\text { study }\end{array}$ & $\begin{array}{l}\text { Iron and foliate } \\
\text { supplementation } \\
\text {, Nutritional } \\
\text { counseling, } \\
\text { Taking snacks } \\
\text { during } \\
\text { pregnancy, } \\
\text { Maternal MUAC, } \\
\text { Anemia, } \\
\text { Minimum dietary } \\
\text { diversity score of } \\
\text { women }\end{array}$ & $\begin{array}{l}\text { Low birth } \\
\text { weight }\end{array}$ & $\begin{array}{l}\text { No iron supplements, no } \\
\text { nutritional counseling, no snack } \\
\text { intake, malnutrition, anemia and } \\
\text { an inadequate minimum dietary } \\
\text { diversity score of women are } \\
\text { factors related with low birth } \\
\text { weight. } \\
(p=0.005)\end{array}$ \\
\hline $\begin{array}{l}\text { Hailu and } \\
\text { Kebede, } \\
2018\end{array}$ & $\begin{array}{l}\text { Determinants of } \\
\text { Low Birth } \\
\text { Weight among } \\
\text { Deliveries at a } \\
\text { Referral Hospital } \\
\text { in Northern } \\
\text { Ethiopia. }\end{array}$ & $\begin{array}{l}\text { Case- } \\
\text { control } \\
\text { study }\end{array}$ & $\begin{array}{l}\text { Sociodemograph } \\
\text { ic, maternal and } \\
\text { obstetric, } \\
\text { gestational age } \\
\text { and history of } \\
\text { pregnancy } \\
\text { complications }\end{array}$ & $\begin{array}{l}\text { Low birth } \\
\text { weight }\end{array}$ & $\begin{array}{l}\text { Preterm delivery, history of } \\
\text { physical trauma during } \\
\text { pregnancy, and history of } \\
\text { pregnancy complications were } \\
\text { predictors of low birth weight, } \\
\text { whereas gender of newborns, } \\
\text { maternal age, maternal parity, } \\
\text { ANC visits, and maternal } \\
\text { hemoglobin levels were not } \\
\text { significantly associated with low } \\
\text { birth weight. } \\
(p=0.139)\end{array}$ \\
\hline $\begin{array}{l}\text { Heydarpo } \\
\text { ur et al., } \\
2019\end{array}$ & $\begin{array}{l}\text { Maternal anemia } \\
\text { in various } \\
\text { trimesters and } \\
\text { related } \\
\text { pregnancy } \\
\text { outcomes: } \\
\text { Results from a } \\
\text { large cohort } \\
\text { study in Iran }\end{array}$ & $\begin{array}{l}\text { Retrospec } \\
\text { tive } \\
\text { cohort } \\
\text { study }\end{array}$ & $\begin{array}{l}\text { Pregnancy } \\
\text { outcome (Birth } \\
\text { outcome, type } \\
\text { delivery, birth } \\
\text { weight, FBS, GTT, } \\
\text { gestational } \\
\text { diabetes, } \\
\text { gestational age, } \\
\text { Abortion) }\end{array}$ & Anemia & $\begin{array}{l}\text { Neonatal mortality was } \\
\text { significantly higher and the } \\
\text { likelihood of a cesarean delivery } \\
\text { was significantly lower in } \\
\text { women who developed anemia } \\
\text { during the first trimester. The } \\
\text { likelihood of pre-term delivery } \\
\text { and abortion was significantly } \\
\text { higher if women had anemia } \\
\text { during the third trimester, while } \\
\text { the likelihood of low birth weight } \\
\text { was lower in women with } \\
\text { anemia during the third } \\
\text { trimester than in those without } \\
\text { anemia (p = 0.199). }\end{array}$ \\
\hline
\end{tabular}


Table 2. Summary of the Literatures (Continued...)

\begin{tabular}{|c|c|c|c|c|c|}
\hline Authors & Article Title & $\begin{array}{l}\text { Research } \\
\text { Methods }\end{array}$ & $\begin{array}{c}\text { Independent } \\
\text { Variable }\end{array}$ & $\begin{array}{c}\text { Dependent } \\
\text { Variable }\end{array}$ & Result \\
\hline $\begin{array}{l}\text { Kumari et } \\
\text { al., } 2019\end{array}$ & $\begin{array}{l}\text { Maternal and } \\
\text { severe anemia in } \\
\text { delivering } \\
\text { women is } \\
\text { associated with } \\
\text { risk of preterm } \\
\text { and low birth } \\
\text { weight: A cross } \\
\text { sectional study } \\
\text { from Jharkhand, } \\
\text { India. }\end{array}$ & $\begin{array}{l}\text { cross- } \\
\text { sectional } \\
\text { study }\end{array}$ & $\begin{array}{l}\text { hemoglobin } \\
\text { concentration }\end{array}$ & $\begin{array}{l}\text { Preterm } \\
\text { and low } \\
\text { birth } \\
\text { weight }\end{array}$ & $\begin{array}{l}\text { The risk of PTB and LBW depends } \\
\text { on the stratification of the anemia } \\
\text { group, because the strongest } \\
\text { association was observed in } \\
\text { severe anemia followed by mild } \\
\text { and moderate anemia in PTB; } \\
\text { whereas the risk of LBW was } \\
\text { found in severe anemia followed } \\
\text { by moderate and mild anemia. } \\
\text { The risks of PTB and LBW in the } \\
\text { six gestational hemoglobin } \\
\text { groups were compared, } \\
\text { hemoglobin } 10 \text { - } 10.9 \text { g / dl and } \leq \\
8 \text { g / dl respectively have shown } \\
\text { an correlations with PTB and } \\
\text { LBW. However, high hemoglobin } \\
\text { concentration was not related } \\
\text { with PTB or LBW (p = 0.683) }\end{array}$ \\
\hline $\begin{array}{l}\text { Nazirun, } \\
2019\end{array}$ & $\begin{array}{l}\text { Factors Related } \\
\text { to the incidence } \\
\text { of low birth } \\
\text { weight babies at } \\
\text { Arifin Achmad } \\
\text { Pekanbaru Riau } \\
\text { Hospital. }\end{array}$ & $\begin{array}{l}\text { case- } \\
\text { control } \\
\text { study }\end{array}$ & $\begin{array}{l}\text { Parity, Distance } \\
\text { Birth, Anemia, } \\
\text { Disease in } \\
\text { Pregnancy, Age } \\
\text { Mothers, } \\
\text { Educatiom, } \\
\text { Mothers work }\end{array}$ & $\begin{array}{l}\text { Low birth } \\
\text { weight }\end{array}$ & $\begin{array}{l}\text { There is a relationship of the most } \\
\text { related variables, namely } \\
\text { maternal education, birth } \\
\text { distance and anemia to the } \\
\text { incidence of LBW }(\mathrm{p}=0.043)\end{array}$ \\
\hline $\begin{array}{l}\text { Oladeind } \\
\text { e et al., } \\
2015\end{array}$ & $\begin{array}{l}\text { Prevalence and } \\
\text { determinants of } \\
\text { low birth weight: } \\
\text { The situation in a } \\
\text { traditional birth } \\
\text { home in Benin } \\
\text { city, Nigeria }\end{array}$ & $\begin{array}{l}\text { cross- } \\
\text { sectional } \\
\text { study }\end{array}$ & $\begin{array}{l}\text { Maternal } \\
\text { hemoglobin level }\end{array}$ & $\begin{array}{l}\text { Low birth } \\
\text { weight }\end{array}$ & $\begin{array}{l}\text { Maternal age, gestational age, } \\
\text { maternal height, marital status, } \\
\text { and trimester were associated } \\
\text { with LBW prevalence. The } \\
\text { prevalence of LBW was not } \\
\text { significantly affected by parity } \\
\text { and educational status for } \\
\text { maternal anemia was identified } \\
\text { as a risk factor for delivering LBW } \\
\text { babies }(p=0.001 \text { ) }\end{array}$ \\
\hline $\begin{array}{l}\text { Roopnari } \\
\text { ne and } \\
\text { Maharaj, } \\
2017\end{array}$ & $\begin{array}{l}\text { Risk factors for } \\
\text { low birthweight } \\
\text { in Southwest } \\
\text { Trinidad: A case- } \\
\text { control study }\end{array}$ & $\begin{array}{l}\text { case- } \\
\text { control } \\
\text { study }\end{array}$ & $\begin{array}{l}\text { Maternal age, } \\
\text { Booking weight, } \\
\text { Maternal weight } \\
\text { gain, Parity, } \\
\text { Antenatal Care, } \\
\text { Blood Count, } \\
\text { Complications, } \\
\text { Employment, } \\
\text { Infant Gender, } \\
\text { Delivery type }\end{array}$ & $\begin{array}{l}\text { Low birth } \\
\text { weight }\end{array}$ & $\begin{array}{l}\text { Factors predicting low birth } \\
\text { weight are maternal age, } \\
\text { maternal weight, low weight gain. } \\
\text { While factors that were not } \\
\text { predictors of birth weight in the } \\
\text { study were parity, maternal } \\
\text { anemia and job status }(\mathrm{p}=0.677) \text {. }\end{array}$ \\
\hline $\begin{array}{l}\text { Sharma et } \\
\text { al., } 2015\end{array}$ & $\begin{array}{l}\text { Low birth weight } \\
\text { at term and its } \\
\text { determinants in } \\
\text { a tertiary } \\
\text { hospital of nepal: } \\
\text { A case-control } \\
\text { study }\end{array}$ & $\begin{array}{l}\text { retrospec } \\
\text { tive case- } \\
\text { control } \\
\text { study }\end{array}$ & $\begin{array}{l}\text { History of } \\
\text { premature } \\
\text { delivery, Hard } \\
\text { physical work, } \\
\text { Age group, } \\
\text { Hemoglobin } \\
\text { level, Ate meat, } \\
\text { bean and green } \\
\text { vegetables } \\
\text { regularly, Height } \\
\text { of Mother, } \\
\text { Ethnicity, Type } \\
\text { of family }\end{array}$ & $\begin{array}{l}\text { Low birth } \\
\text { weight }\end{array}$ & $\begin{array}{l}\text { A history of preterm labor, hard } \\
\text { physical work during pregnancy, } \\
\text { younger maternal age, mothers } \\
\text { with hemoglobin levels less than } \\
11 \mathrm{~g} / \mathrm{dl} \text {, and lack of consumption } \\
\text { of nutritious foods during } \\
\text { pregnancy were significantly } \\
\text { associated with the birth of LBW } \\
\text { babies }(\mathrm{p}=0.077)\end{array}$ \\
\hline
\end{tabular}


the odds ratio varied widely, starting from OR 1.12 (Kumari et al., 2019) to the highest with an OR 14.5 (Aboye et al., 2018). The results of this study are in line with Hailu's (2018) study which states that maternal hemoglobin levels do not have a significant relationship with low birth weight. This can be caused by other factors that can affect the incidence of low birth weight such as, the mother's age less than 20 years or more than 35 years, the number of parity, pregnancy spacing and the existence of problems in previous pregnancy and childbirth, such as bleeding, preeclampsia, high fever, prolonged labor ( $>12$ hours), delivery by operation and stillbirth (Dinas Kesehatan Kota Surabaya, 2017). In infants with normal birth weight, there was an anemia incidence rate of 24 people $(31.6 \%)$. This could be due to other factors such as gestational age, the most atrisk mothers with gestational age $<37$ weeks are 79 people $(52.0 \%)$ and mothers are not at risk with gestational age 37-41 weeks as many as 73 people ( $48.0 \%$ ) (Normayanti, 2019).

The results of other studies that maternal hemoglobin and serum ferritin were found to affect pregnancy outcomes (birth weight, height, and gestational age). Newborns of women with low $\mathrm{Hb}$ levels tend to have lower birth weight and height, head circumference, and lower gestational age. A statistically significant difference was observed between the $\mathrm{Hb}$ tertile groups when compared to maternal serum ferritin, where serum ferritin levels increased with increasing $\mathrm{Hb}$ levels. There was a significant association between low maternal serum ferritin and the frequency of low birth weight and the frequency of preterm labor. Newborns born to women with low Hb levels tend to have lower birth weight and height, head circumference, and lower gestational age (Srour et al., 2018). Serum ferritin is used to determine iron deficiency. There are several physiological changes that occur pregnancy which may contribute to threshold variation serum ferritin-defined iron deficiency in pregnancy (Daru et al., 2017).

Physiologically, pregnant women will experience blood thinning due to the increased need for blood supply to the fetus. Iron deficiency anemia was defined as low serum ferritin concentration $<30 \mu \mathrm{g} / \mathrm{l}$ and hemoglobin $<11.0 \mathrm{~g} / \mathrm{dl},<10.5 \mathrm{~g} / \mathrm{dl}$ in the second trimester, and $11.0 \mathrm{~g} / \mathrm{dl}$ in the third trimester (Robson and Waugh, 2011). Anemia in pregnancy is a risk factor for low birth weight babies. Anemia that occurs during pregnancy is due to the increased need for iron for fetal growth and the needs of pregnant women. The increase in blood volume during pregnancy will increase the need for iron.

Another study showed that anemia results in pregnancy AOR 14.5 (3,821-55.6) were found to be significant with low birth weight. This is because micro-nutritional deficiencies during pregnancy have been shown to have serious implications for the developing fetus, as well as in the results of the study. The possible explanation for LBW might be due to variation in characteristics of study population like nutritional status and maternal feeding habit (Aboye et al., 2018), therefore recommendations for pregnancy are often extrapolated from the estimated intake requirements of adults or adolescents (if appropriate), adjusted to account for fetal nutrient accumulation, additional maternal needs to support tissue gain and metabolism, and changes in nutrient absorption efficiency that may occur during pregnancy (Gernand et al., 2016)

Kaur et al (2015) also revealed that a significant correlations for neonatal birth weight, length and head circumference with maternal hemoglobin levels. This can be because during pregnancy, pregnant women often experience iron deficiency in the body. Iron is needed to form red blood cells (hemoglobin) besides that it also functions in the body's defense system, as well as in the research of Girma et al which stated that anemia in pregnant women $(\mathrm{AOR}=3.54,95 \%$ $\mathrm{CI}, 1.46-8.61$ ) is a factor related with low birth weight. This is because micronutrient deficiency during pregnancy has been shown to have serious implications for fetal development and hence, birth weight (Girma et al., 2019). This studies in line with the research conducted by Lumbanraja et al. Conducted in Indonesia where the antepartum hemoglobin concentration has a statistically significant correlation with hemoglobin concentration during pregnancy. Of the 200 pregnant women in the study, 
more than half (52.5\%) of them had anemia (Lumbanraja et al., 2019).

Anemia occurs because the number of red blood cells has decreased. During pregnancy, the blood in the mother's body is hemodiluted due to an increase in blood volume by an average of $40-45 \%$. The factors that influence the incidence of low birth weight babies in developing countries are different from those in developed countries. In developed countries the incidence of low birth weight babies is influenced by smoking habits, maternal caloric intake and insufficient weight gain during pregnancy, lack of pre-pregnancy weight, maternal height, premature babies, ethnicity/race, gender. In developing countries, low birth weight babies are influenced by the mother's calorie intake, less weight gain during pregnancy, less weight before pregnancy, malaria, the mother's height and the sex of the baby (WHO, 1992).

A systematic review study that discusses hemoglobin levels per trimester, the results of a combination cohort, case control and cross sectional study used a randomized effect model showed a significant relationship between maternal anemia and LBW in the first trimester with RR 1.26 (95\% $\mathrm{Cl}: 1.03$ - 1.55). This is because in studies using a cohort, it has the highest weight because of the large sample size. The results of the relationship between second trimester hemoglobin levels showed insignificant results with the meta-analysis of RR 0.97 (95\% CI: 0.57-1.66), and the results of the third trimester $\mathrm{Hb}$ level with LBW was RR 1.21 (95\% CI: 0.84 - 1.76) using an effect model randomized and no significant correlation was observed between maternal anemia in the third trimester of pregnancy and LBW (Rahmati et al., 2017). In Figueiredo et al's study in their systematic review, the results of the meta-analysis summarized an odds ratio of 1.49 (95\% CI: $1.36,1.63)$ which shows a statistically significant relationship between maternal anemia and low birth weight (Figueiredo et al., 2018). In Azami et al (2016) to prevent anemia by providing training in proper nutrition during pregnancy and training in the correct use of iron, vitamins, and folic acid supplements should be regulated and carried out in a prenatal clinic or before marriage.

\section{CONCLUSION}

The conclusion is that there is no significant relationship between the $\mathrm{HB}$ level of pregnant women $\leq 11 \mathrm{~g} / \mathrm{dL}$ and the incidence of LBW ( $p=0.074)$. There are other factors that influence the research such as differences in characteristics, number of samples, studies in different countries, different trimester of pregnancy and other factors that can cause research bias. Therefore, in the event of low birth weight, monitoring of hemoglobin since antenatal and taking supplements must be carefully monitored. For further research, data searches can be carried out on international journal site providers with a wider span of years, limiting the sample, using one of the research methods so that they can display more complete results.

\section{CONFLICT OF INTEREST}

The authors declare the absence of conflict of interest

\section{REFERENCES}

Aboye, W., Berhe, T., Birhane, T. and Gerensea, H. (2018) 'Prevalence and associated factors of low birth weight in Axum town, Tigray, North Ethiopia', $B M C$ Research Notes. BioMed Central, 11(1), pp. 1-6. doi: 10.1186/s13104-0183801-z.

Ahankari, A., Bapat, S., Myles, P., Fogarty, A. and Tata, L. (2017) 'Factors associated with preterm delivery and low birth weight: A study from rural Maharashtra, India', F1000Research, 6(May), pp. 1-12. doi: 10.12688/f1000research.10659.1.

Daru, J., Allotey, J., Peña-Rosas, J. P. and Khan, K. S. (2017) 'Serum ferritin thresholds for the diagnosis of iron deficiency in pregnancy: a systematic review', Transfusion Medicine, 27(3), pp. 167174. doi: 10.1111/tme.12408.

Dinas Kesehatan Kota Surabaya. (2017) 'Profil Kesehatan Kota Surabaya Tahun 2017', Surabaya: Dinas Kesehatan Kota Surabaya

Figueiredo, A. C. M. G., Gomes-Filho, I. S., Silva, R. B., Pereira, P. P. S., Da Mata, F. A. F., Lyrio, A. O., Souza, E. S., Cruz, S. S. and 
Pereira, M. G. (2018) 'Maternal anemia and low birth weight: A systematic review and meta-analysis', Nutrients, 10(5), pp. 1-17. doi: $10.3390 /$ nu10050601.

Fitriany, J. and Saputri, A. I. (2018) 'Anemia Defisiensi Besi', AVERROUS: Jurnal Kedokteran dan Kesehatan Malikussaleh, 4(2), p. $1 . \quad$ doi: 10.29103/averrous.v4i2.1033.

Gernand, A. D., Schulze, K. J., Stewart, C. P., West, K. P. and Christian, P. (2016) 'Micronutrient deficiencies in pregnancy worldwide: health effects and prevention', Nature reviews. Endocrinology, 12(5), pp. 274-289. doi: 10.1038/nrendo.2016.37.Micronutrient.

Girma, S., Fikadu, T., Agdew, E., Haftu, D., Gedamu, G., Dewana, Z. and Getachew, B. (2019) 'Factors associated with low birthweight among newborns delivered at public health facilities of Nekemte town, West Ethiopia: A case control study', BMC Pregnancy and Childbirth. BMC Pregnancy and Childbirth, 19(1), pp. 1-6. doi: 10.1186/s12884-0192372-x.

Hailu, L. D. and Kebede, D. L. (2018) 'Determinants of Low Birth Weight among Deliveries at a Referral Hospital in Northern Ethiopia', BioMed Research International, 2018, pp. 1-8. doi: 10.1155/2018/8169615.

Heydarpour, F., Soltani, M., Najafi, F., Tabatabaee, H. R., Etemad, K., Hajipour, M., Babanejad, M., Valadbeigi, T., Yaghoobi, H. and Rezaeian, S. (2019) 'Maternal anemia in various trimesters and related pregnancy outcomes: Results from a large cohort study in Iran', Iranian Journal of Pediatrics, 29(1), pp. 1-7. doi: 10.5812/ijp.69741.

Kumari, S., Garg, N., Kumar, A., Guru, P. K. I., Ansari, S., Anwar, S., Singh, K. P., Kumari, P., Mishra, P. K., Gupta, B. K., Nehar, S., Sharma, A. K., Raziuddin, M. and Sohail, M. (2019) 'Maternal and severe anaemia in delivering women is associated with risk of preterm and low birth weight: $A$ cross sectional study from Jharkhand, India', One Health. Elsevier, 8(July), p.
100098.

doi:

10.1016/j.onehlt.2019.100098.

Lumbanraja, S. N., Yaznil, R. M., Siregar, D. I. S. and Sakina, A. (2019) 'The correlation between hemoglobin concentration during pregnancy with the maternal and neonatal outcome', Open Access Macedonian Journal of Medical Sciences, 7(4), pp. 594-598. doi: 10.3889/OAMJMS.2019.150.

Nazirun, N. (2019) 'Factors related to the incidence of low birth weight babies at Arifin Achmad Pekanbaru Riau Hospital', Annals of Tropical Medicine \& Public Health S318, 11.

Normayanti (2019) 'Hubungan Anemia Pada Ibu Hamil Dengan Kejadian BBLR Di RS PKU Muhammadiyah Yogyakarta', Universitas Aisiyah Yogyakarta.

Novianti, S. and Aisyah, I. S. (2018) 'Hubungan Anemia Pada Ibu Hamil Dan Bblr', Jurnal Siliwangi, 4(1), pp. 6-8. Available at: http://jurnal.unsil.ac.id/index.php/jssai nstek/article/view/440\%0A18-082019.

Oladeinde, H. B., Oladeinde, O. B., Omoregie, R. and Onifade, A. A. (2015) 'Prevalence and determinants of low birth weight: The situation in a traditional birth home in Benin city, Nigeria', African Health Sciences, 15(4), pp. 1123-1129. doi: 10.4314/ahs.v15i4.10.

Rahmati, S., Delpishe, A., Ahmadi, M. R. H. and Sayehmiri, K. (2017) 'Maternal anemia during pregnancy and infant low birth weight: A systematic review and metaanalysis', International Journal of Reproductive BioMedicine, 15(3), pp. 125-134. doi: 10.29252/ijrm.15.3.125.

Robson, S. and Waugh, J. (2011) Patologi Pada Kehamilan: Manajemen dan Asuhan Kebidanan. Jakarta: EGC.

Roopnarine, N. C. and Maharaj, R. G. (2017) 'Risk factors for low birthweight in Southwest Trinidad: A case-control study', West Indian Medical Journal, 66(1), pp. 88-94. doi: 10.7727/wimj.2014.161. 
Sharma, S. R., Giri, S., Timalsina, U., Bhandari, S. S., Basyal, B., Wagle, K. and Shrestha, L. (2015) 'Low birth weight at term and its determinants in a tertiary hospital of nepal:A case-control study', PLoS ONE, 10(4), pp. 1-10. doi: 10.1371/journal.pone.0123962.

Srour, M. A., Aqel, S. S., Srour, K. M., Younis, K. R. and Samarah, F. (2018) 'Prevalence of Anemia and Iron Deficiency among Palestinian Pregnant Women and Its Association with Pregnancy Outcome',
Anemia,

2018.

doi: 10.1155/2018/9135625.

United Nations Children's Fund. (2004). Low Birthweight: Country, regional and global estimates. New York: UNICEF.

World Health Organization. (2004). Low Birthweight: Country, Regional dan Global Estimates. Geneva.

World Health Organization. (1992) 'Low Birth Weight: Tabulation of Available Information'. Geneva. 